\title{
KRIMINALISASI DITINJAU DARI PERSPEKTIF TEORI HUKUM PIDANA (CRIMINAL LAW THEORY)
}

\author{
Marthen H. Toelle \\ Advokat/Praktisi Hukum di Bidang Jasa Konstruksi \\ dan Pengadaan Barang/Jasa Pemerintah \\ Korespondensi: marthentoelle@yahoo.com
}

\begin{abstract}
Abstrak
Tulisan ini mengkritisi kriminalisasi oleh legislator ditinjau dari perspektif Teori Hukum Pidana. Keputusan legislator untuk mengkriminalkan suatu tindakan melalui undangundang perlu dibatasi karena sangat mempengaruhi kebebasan individu. Di negara berdasarkan pada asas the Rule of Law (negara hukum), pembatasan kekuasaan legislator bersifat niscaya. Khusus terkait dengan keputusan legislator dalam melakukan kriminalisasi, bentuk pembatasan tersebut dapat dilakukan salah satunya dengan jalan membedakan antara kriminalisasi yang legitimate dengan kriminalisasi yang tidak legitimate. Melakukan pembedaan tersebut merupakan salah satu bidang kajian dari Teori Hukum Pidana dengan tujuan supaya undang-undang pidana yang dihasilkan dalam proses kriminalisasi mengandung kebenaran.
\end{abstract}

Kata-kata Kunci: Kriminalisasi; Legislator; Pembatasan.

\begin{abstract}
This article tries to criticize the legistature's decision to criminalize from the Criminal Law Theory perspective. The legislature's decision to criminalize needs to be limited because it has great impacts over civil liberties. According to the Rule of Law principle, the limitation over legislative power is inescapable. Specifically related to the legislature's decision to criminalize, the forms of limitation can be undertaken by differentiate between the legitimate criminalization and the illegitimate criminalization. Doing this differentiation is analytically one of the main concerns of the Criminal Law Theory in order to satisfy that the criminal law resulted from the criminalization process is really needed.
\end{abstract}

Key Words: Criminalization; Legislature; Limitation. 


\section{PENDAHULUAN}

Tulisan ini menggunakan optik Teori Hukum Pidana untuk mengkaji dan mengkritisi isu konseptual mengenai kriminalisasi. Yang dimaksud dengan Teori Hukum Pidana atau Criminal Law Theory (Criminal Theory) adalah "the enterprise of subjecting criminal doctrine and its procedures to critical scrutiny. It seeks to tell the story of criminal law in a way which offers more than a merely descriptive account of the rules and procedures governing criminal liability." Dengan optik tersebut maka tulisan ini tidak akan mendiskusikan ketentuan hukum pidana spesifik yang meliputi kegiatan interpretasi atas ketentuan tersebut untuk menentukan ruang lingkup keberlakuannya atau menentukan makna spesifik dari unsurunsur yang ada di dalamnya. Hal demikian adalah ranah pembahasan oleh Dogmatika Hukum Pidana.

Kriminalisasi menjadi isu sangat serius untuk didiskusikan dewasa ini karena terlalu banyaknya pengaturan yang dilakukan oleh negara (melalui pembentuk undang-undang) dengan disertai ancaman sanksi pidana. Kondisi demikian sangat memprihatinkan karena kriminalisasi sangat mempengaruhi kebebasan individu (civil liberties). Oleh karena itu, kriminalisasi tidak boleh dipandang sebagai kewenangan absolut pembentuk undang-undang, satu paket dengan kekuasaan legislasi yang dimilikinya untuk digunakan secara bebas.
Melihat perkembangan dalam kriminalisasi yang demikian pesat maka kekuasaan pembentuk undang-undang dalam menetapkan suatu tindakan sebagai tindak pidana beserta ancaman sanksi pidananya sangat perlu untuk dikritisi. Negara dengan terlalu banyak undang-undang pidana pada hakikatnya memiliki semangat tersirat untuk mengekang kebebasan individu. Politik hukum demikian tentu tidak sepatutnya dibiarkan.

Atas dasar itu maka tulisan ini hendak berargumen tentang perlunya suatu kriminalisasi dibedakan secara substansial antara kriminalisasi yang legitimate dengan kriminalisasi yang tidak legitimate. Alasan fundamental di balik pembedaan tersebut adalah perlunya pembatasan terhadap kekuasaan untuk melakukan kriminalisasi yang dimiliki oleh pembentuk undang-undang. Dengan demikian temuan atau hasil dari pembahasan ini adalah kriteria yang sifatnya prinsipiil mengenai kriminalisasi yang dikehendaki secara substantif, yaitu kriminalisasi yang legitimate. Kriminalisasi yang tidak legitimate adalah praktik penggunaan kekuasaan legislasi yang seyogianya dihindari.

\section{PEMBAHASAN}

\section{Kriminalisasi dan the Rule of Law}

Kriminalisasi pada hakikat-nya merupakan pintu masuk bagi 
keberlakuan hukum pidana (material). Yang dimaksud dengan hukum pidana menurut Moeljatno adalah:

bagian daripada keseluruhan hukum yang berlaku di suatu negara, yang mengadakan dasar-dasar dan aturanaturan untuk:

1) Menentukan perbuatan-perbuatan mana yang tidak boleh dilakukan, yang dilarang, dengan disertai ancaman atau sanksi yang berupa pidana tertentu bagi barangsiapa melanggar larangan tersebut.

2) Menentukan kapan dan dalam halhal apa kepada mereka yang telah melanggar larangan-larangan itu dapat dikenakan atau dijatuhi pidana sebagaimana yang telah diancamkan.

3) Menentukan dengan cara bagaimana pengenaan pidana itu dapat dilaksanakan apabila ada orang yang disangka telah melanggar larangan tersebut. ${ }^{2}$

Kriminalisasi menurut Persak adalah "defining certain human conduct (acts or omissions) as criminal offences and usually assigning to them a certain range of criminal-law sanctions" (menentukan suatu tindakan sebagai tindak pidana dan memberlakukan ancaman sanksi pidana atas tindak pidana tersebut). ${ }^{3}$ Dihubungkan dengan pendapat Moeljatno maka konsep kriminalisasi dari Persak merupakan unsur pertama dalam pengertian hukum pidana.

Berdasarkan Pasal 1 ayat (1) Kitab Undang-undang Hukum Pidana (KUHP) yang dikenal sebagai asas legalitas, suatu tindakan dapat dikualifikasi sebagai tindak pidana manakala negara telah melakukan kriminalisasi terhadap tindakan tersebut melalui undangundang (legislasi). Moeljatno menjelaskan hal ini sebagai berikut:

mengenai dilarang dan diancamnya suatu perbuatan, yaitu mengenai perbuatan pidananya sendiri, mengenai criminal act, juga ada dasar yang pokok, yaitu azas legalitas (Principle of legality), azas yang menentukan bahwa tidak ada perbuatan yang dilarang dan diancam dengan pidana jika tidak ditentukan terlebih dahulu dalam perundangundangan. Biasanya ini dikenal dalam bahasa Latin sebagai Nullum delictum nulla poena sine praevia lege poenali (tidak ada delik, tidak ada pidana tanpa peraturan terlebih dahulu. ${ }^{4}$

Pada pendapat di atas ada hal yang perlu diberikan catatan oleh penulis yaitu konsep "perundang-undangan" sebagaimana dimaksudkan oleh Moeljatno pada hakikatnya adalah undang-undang (legislasi).

Konseptor asas legalitas dalam pengertian di atas adalah Anselm von Feurbach (1775-1833), sarjana Jerman, yang mengemukakan teori vom psychologischen zwang. Teori tersebut merupakan landasan teoretis bagi asas legalitas dengan pengertian:

supaya dalam menentukan perbuatanperbuatan yang dilarang di dalam peraturan bukan saja tentang macamnya perbuatan yang harus dituliskan dengan jelas, tetapi juga tentang macamnya pidana yang diancamkan. Dengan cara demikian ini, maka oleh orang yang akan melakukan

2 Moeljatno, Asas-asas Hukum Pidana ( Penerbit Rineka Cipta 1993) 1.

3 Nina Persak, Criminalising Harmful Conduct: The Harm Principle, Its Limits and Continental Counterparts (Springer 2007) 6.

$4 \quad$ Moeljatno, Op.Cit. 23. 
perbuatan yang dilarang tadi lebih dahulu telah diketahui pidana apa yang akan dijatuhkan kepadanya jika nanti perbuatan itu dilakukan. Dengan demikian dalam batinnya, dalam psychen-nya, lalu diadakan tem atau tekanan untuk tidak berbuat. Dan kalau toh dia melakukan perbuatan tadi, maka hal dijatuhi pidana kepadanya itu bisa dipandang sebagai sudah disetujuinya sendiri. ${ }^{5}$

Selain fungsi preventif pada diri orang yang potensial melakukan tindakan, asas legalitas juga berfungsi pembatasan kekuasaan supaya tidak terjadi kesewenang-wenangan dalam menggunakan hukum pidana oleh penguasa. Hal ini secara historis dipengaruhi oleh konsep hukum Romawi yaitu crimina extra ordinaria (kejahatankejahatan yang tidak disebut dalam undang-undang). Dalam praktiknya, konsep hukum tersebut banyak disalahgunakan oleh raja-raja pada era absolutisme, sehingga dibutuhkan pembatasan terhadap potensi penyalahgunaan hukum pidana oleh penguasa dengan asas legalitas. Hasilnya adalah perumusan asas legalitas dalam Pasal 8 Declaration des droits de L'homme et du citoyen (1789) setelah berakhirnya Revolusi Perancis dan kemudian dimuat dalam Pasal 4 Code Penal Perancis di bawah pemerintahan Napoleon, dan selanjutnya diberlakukan dalam Wetboek van Strafrecht Belanda (1881) dan dengan asas konkordansi diberlakukan ke dalam Pasal 1 KUHP (1918). ${ }^{6}$

Ibid. 25

\footnotetext{
$6 \quad$ Ibid. 24-25.
}

Berdasarkan penjelasan di atas dapat disimpulkan bahwa menentukan suatu tindakan sebagai tindak pidana (kriminalisasi) merupakan wilayah kewenangan negara dalam diri pembentuk undang-undang (legislator). Sesuai asas negara hukum, maka tindakan negara dalam melakukan kriminalisasi memiliki batasan-batasan agar tindakan tersebut tidak sewenangwenang dan merugikan warga negara. Dalam melakukan kriminalisasi kewenangan legislator tidak bebas (tidak tanpa batas). Oleh karena itu pembatasan terhadap kewenangan legislator untuk melakukan kriminalisasi perlu dianalisis secara khusus terutama untuk menjawab permasalahan cakupan kriminalisasi yang diperbolehkan dan yang tidak diperbolehkan. Dengan pengertian lain, analisis yang dilakukan akan difokuskan pada kriteria kriminalisasi yang diperbolehkan atau kriminalisasi yang legitimate.

Berdasarkan Pasal 1 ayat (1) KUHP yang lazim dikenal dengan predikat asas legalitas, kriminalisasi adalah tindakan negara dalam menetapkan suatu tindakan sebagai tindak pidana (beserta sanksi pidananya) ke dalam undangundang (legislasi). ${ }^{7}$ Dengan pengertian yang demikian maka kriminalisasi adalah tindakan negara dalam rulemaking untuk menghasilkan legislasi pidana (hukum pidana materiil). Secara teoretis, kekuasaan rule-making untuk menghasilkan legislasi (undang-undang) 
adalah kekuasaan formal negara yang bersifat monopolistik dan diwakili oleh pemerintah sebagai legislator. Oleh karena itu maka pertanyaan pokoknya kemudian adalah apakah ada batasan terhadap kekuasaan negara dalam melakukan kriminalisasi? Pertanyaan ini perlu didiskusikan karena alasanalasan:

First, "of all branches of law, criminal law is most obviously and directly concerned with shaping and controlling human conduct." Second, the criminal law enforces the most important behavioral values imposed by a state. Third, the criminal law expresses the highest legal condemnation of acts in a society. Perhaps most important, the criminal law applies the highest legal sanctions available to a society: deprivation of freedom, confiscation of property, and in some societies, death. As a result, the need for fairness of both substantive and procedural rules is at its greatest here. ${ }^{8}$

Isu mengenai batasan terhadap kekuasaan kriminalisasi negara sangat penting supaya tidak terjadi praktik overcriminalization. Husak mengemukakan dua alasan mengapa overcriminalization tidak dikehendaki: "First, overcriminalization almost certainly results in too much punishmentpunishment that is undeserved and unjustified. Second, overcriminalization threatens the rule of law." Atas dasar itu maka dalam koridor the Rule of Law, kekuasaan negara melakukan kriminalisasi adalah tidak tanpa batas (tidak unlimited). Artinya, negara tidak free to legislate dan sekaligus tidak free to criminalize tanpa adanya batasan sedikitpun. The Rule of Law meletakkan batasan umum terhadap kekuasaan legislasi negara dan batasan khusus terhadap kekuasaan kriminalisasi negara. ${ }^{10}$

Asas the Rule of Law menurut Raz mengandung sejumlah nilai yaitu: pertama, berkenaan dengan kemampuan untuk 'choose styles and forms of life, to fix long-term goals and effectively direct one's life towards them' yang sangat terbantu oleh the Rule of Law. Kedua, perlindungan kebebasan individu. Hal ini berkaitan dengan penciptaan prediktabilitas oleh the Rule of Law yang meningkatkan kebebasan individu dalam memilih sebanyak mungkin opsi yang ada dalam menjalani hidupnya. Ketiga, the Rule of Law dimaksudkan untuk meminimalisir 'the danger created by the law itself' seperti: unstable, obscure, retrospective, dan lain-

$7 \quad$ Tentang hakikat asas legalitas Peter Mahmud Marzuki mengatakan: "The principle of legality is based on the elementary notion of justice that the criminal law should be as fixed and certain as possible in order that people may know in advance what act is criminal." Peter Mahmud Marzuki, An Introduction to Indonesian Law (Setara Press 2011) 174.

8 Kenneth S. Gallant, The Principle of Legality in International and Comparative Criminal Law (Cambridge University Press 2009) 16-17.

9 Douglas Husak, 'Overcriminalization' dalam Dennis Patterson, ed., A Companion to Philosophy of Law and Legal Theory (Blackwell Publishing Co., 2010) 623. Isu ini rupanya juga tidak luput dari perhatian Moeljatno, hanya alasannya berbeda dikaitkan dengan kemampuan aparat penegak hukum untuk berlaku konsisten dalam melaksanakan ancaman pidana di dalam undang-undang. Moeljatno mengatakan: "kalau kebanyakan perbuatan melawan hukum dijadikan perbuatan pidana, sehingga tidak sesuai lagi dengan kebutuhan masyarakat menurut perasaan hukum yang hidup di dalamnya, maka akibatnya timbullah inflasi pidana, sehingga penghargaan terhadapnya tidak sebagaimana mestinya lagi.” Moeljatno, Op.Cit. 4. 
lain yang dapat melanggar kebebasan dan martabat manusia. Keempat, memastikan pencapaian tujuan hukum baik secara langsung maupun tidak langsung dengan jalan 'conformity with the law in itself and thus further consequences of conformity with the law or knowledge of its existence which the law is intended to secure. ${ }^{11}$

Argumentasi lebih komprehensif tentang aspek nilai dari the Rule of Law (dalam kaitan dengan aktivitas pengaturan oleh negara) dikemukakan oleh Sunstein dalam defending rules as rules. Pertama, rules minimize the informational and political costs of reaching decisions in particular cases. Kedua, rules are impersonal and blind; they promote equal treatment and reduce the likelihood of bias and arbitrariness. Ketiga, rules serve appropriately both to embolden and constrain decision-makers in particular cases. Keempat, rules promote predictability and planning for private actors and for the government. Kelima, rules increase visibility and accountability. Keenam, rules avoid the humiliation of subjecting people to exercises of official discretion in their particular case. Ketujuh, rules promote equal application of the law. ${ }^{12}$ Atas dasar pengetahuan tentang nilai-nilai inheren dan mendasar dari the Rule of Law itulah maka the Rule of Law merupakan sebuah keniscayaan, dan konsekuensinya kemudian ialah kerangka pengaturan harus tunduk pada preskripsi the Rule of Law supaya tidak menjadi the rule of arbitrary power dengan berlindung di balik asas legalitas (the Rule of Law dalam arti sempit).

Konsep the Rule of Law di sini digunakan dalam dua tataran pengertian, yaitu dalam arti sempit dan dalam arti luas. Dalam arti sempit:

The rule of law, at its core, requires that government officials and citizens are bound by and act consistent with the law. This basic requirement entails a set of minimal characteristics: law must be set forth in advance (be prospective), be made public, be general, be clear, be stable and certain, and be applied to everyone according to its terms. ${ }^{13}$

Prasyarat ini sifatnya minimal, yaitu a common baseline that all of the competing definitions of the rule of law share. Dalam communis opinio, pengertian ini, the Rule of Law dalam arti sempit di atas, lazim dikonsepsikan dengan istilah legalitas (legality). Dalam konteks isu tentang rule-making di Indonesia, maka the Rule of Law dalam arti sempit adalah Undang-Undang Nomor 11 Tahun 2012 tentang Pembentukan Peraturan Perundangundangan (UU No. 11 Tahun 2012).

Dalam arti luas, the Rule of Law harus mencakup aspek: reference to fundamental rights, democracy, and/or criteria of justice or right. ${ }^{14}$ Karakter dari konsep luas the Rule of Law adalah penekanan pada aspek nilai, tidak hanya legalitas, yang tuntutannya supaya the Rule of Law menjadi the Rule of Good Law.

\footnotetext{
10 Asas Rule of Law dijadikan sebagai rujukan karena menurut Pasal 1 ayat (3) Undang-Undang Dasar Negara Republik Indonesia Tahun 1945 (UUD NRI 1945) Indonesia adalah negara hukum. 11 Joseph Raz, The Authority of Law (Clarendon Press 1983) 220-224.
} 
Sebagai asas/prinsip, the Rule of Law mendikte isu rule-making dalam dua aspek. Pertama, asas ini mempreskripsikan 'needs' untuk rulemaking dalam penyelenggaraan negara. Kedua, asas ini sekaligus meletakkan pembatasan hukum dalam rule-making. Pengertian demikian dikemukakan Inoue:

I argue that this strong structural conception of the rule of law can offer the basis of public legitimacy of legislation that transcends the partisan strife where rival forces with differing specific conceptions of justice compete for victory in legislative politics. It offers normative constraints upon what the political victors can do to the losers in such a way that the losers can respect the products of legislative politics as public decisions of their political society rather than as the private wills of victors. ${ }^{15}$

Berdasarkan uraian di atas maka bentuk pembatasan umum oleh the Rule of Law terhadap kekuasaan rule-making negara adalah peraturan perundangundangan and/or criteria of justice or right.

Selanjutnya adalah bentuk pembatasan khusus oleh the Rule of Law terhadap kekuasaan kriminalisasi negara. Karena dipengaruhi gagasan tentang HAM maka menurut penulis tesis yang seyogianya menjadi acuan sebagai batasan terhadap kekuasaan kriminalisasi negara adalah "the criminalisation ought to be guided by the criminalisation principles that are consistent with the liberal values and, subsequently, that today, legality is not enough, that the emphasis should be put on moral or ethical legitimacy of laws." 16 Tesis Persak di atas menekankan ketidakadekuatan asas legalitas dalam menjustifikasi tindakan kriminalisasi yang dilakukan oleh negara.

Dalam kerangka berpikir Persak diakui adanya peluang sangat besar bagi terjadinya praktik penyalahgunaan kekuasaan dan/atau tindakan sewenang-wenang dalam legislasi untuk mengkriminalisasi suatu tindakan. Konsep liberal values yang dikemukakan oleh Persak tidak asing bagi bangsa Indonesia sejak bangsa ini mengakui HAM sebagai sebagai asas yang harus dijunjung tinggi dalam pemerintahan dengan Perubahan II UUD NRI 1945 yang menghasilkan Bab XA maupun dengan diundangkannya UndangUndang Nomor 39 Tahun 1999 tentang Hak Asasi Manusia (UU No. 39 Tahun 1999). Oleh karena itu maka poin diskusi selanjutnya adalah moral or ethical legitimacy of laws sebagai landasan bagi pembatasan kekuasaan kriminalisasi negara. Konsep moral or ethical legitimacy of laws di sini adalah HAM, yang lebih spesifik lagi menurut Baker adalah the right not to be unfairly criminalized. Baker menjelaskan posisi dari hak tersebut sebagai the moral

12 Cass R. Sunstein, 'Problems with Rules' (1995) 83 California Law Review 953, 972-977.

13 Brian Z. Tamanaha, 'A Concise Guide of the Rule of Law' dalam Gianluigi Palombella dan Neil Walker, eds., Relocating the Rule of Law(Hart Publishing 2009) 3.

14 Ibid. 4. Lihat juga Randall Peerenboom, 'Varieties of Rule of Law' dalam Randall Peerenboom, ed., Asian Discourses of Rule of Law (Routledge 2004) 3.

15 Tatsuo Inoue, 'The Rule of Law as the Law of Legislation' dalam Luc J. Wintgens, ed., Legislation in Context: Essays in Legisprudence (Ashgate Publishing Company 2007) 55. 
criteria for constraining unjust criminalization. Tujuan dari hak tersebut adalah melindungi sejumlah HAM spesifik yaitu free speech, freedom of religion, privacy, dan lain-lain. ${ }^{17}$

\section{Pembatasan terhadap Kekuasaan Kriminalisasi Pembentuk Undang- Undang}

Secara prinsip, hanya pembentuk undang-undang (legislator) yang memiliki kekuasaan untuk menetapkan suatu perbuatan sebagai tindak pidana beserta, sekaligus, sanksi pidana sebagai konsekuensinya. Dikaitkan kembali dengan pembahasan sebelumnya, kekuasaan kriminalisasi yang ada pada pembentuk undangundang adalah implikasi dari keberlakuan asas legalitas berdasarkan asas the Rule of Law. Oleh karena itu, pembahasan ini akan mengelaborasi lebih lanjut pendapat sebelumnya di atas terkait dengan isu pembatasan terhadap kekuasaan kriminalisasi pembentuk undang-undang.

Kriminalisasi harus dibatasi secara ekstra ketat karena dampaknya yang bersifat negatif terhadap kebebasan manusia. Persak menyatakan:

The enactment of the criminal legislation is from the individual's standpoint one of the most intrusive and repressive acts of state power, for it not only restricts his freedom of action but also punishes infringements (often with deprivation of the individual's liberty) ... As the criminal law is the most intrusive of the institutions of formal social control, with lasting and sweeping implications for the individual, it should be, therefore, kept to the minimum. ${ }^{18}$

Secara teoretis, pembatasan terhadap kekuasaan pembentuk undang-undang dalam melakukan kriminalisasi dapat ditujukan pada dua aspek. Pembatasan pertama adalah pembatasan yang ditujukan terhadap kekuasaan legislasinya per se. Pembatasan kedua adalah pembatasan yang ditujukan terhadap substansi kriminalisasinya sendiri. Dengan demikian, pembatasan pertama cenderung bersifat generalis. Sementara pembatasan kedua bersifat specialis.

Sesuai asas the Rule of Law, maka tindakan negara dalam melakukan kriminalisasi memiliki batasan-batasan agar tindakan tersebut tidak sewenangwenang dan merugikan warga negara. Pernyataan ini dapat dikaitkan dengan hakikat konsep negara hukum sebagaimana dijelaskan oleh Tamanaha berikut ini. Menurut Tamanaha, secara konseptual the Rule of Law atau negara hukum memiliki dua fungsi. Pertama, to impose legal restraints on government officials. Fungsi ini dilakukan dengan dua cara. Pertama, government officials must abide by valid positive laws in force at the time of any given action. Konsekuensi yang kemudian timbul: "government actions must have positive legal authorization (without which the action is improper); and no government

16 Nina Persak, Op.Cit. 4.

17 Dennis J. Baker, The Right Not To Be Criminalized: Demarcating Criminal Law's Authority (Ashgate Publishing Company 2011) 1. 
action may contravene a legal prohibition or restriction." 19

Hal itu berarti, dalam kerangka the Rule of Law, untuk memediasi tindakan intervensionis negara kepada warga negara diperlukan adanya hukum positif, yaitu peraturan perundangundangan. Oleh karena itu negara harus melakukan pengaturan. Tetapi meskipun negara yang membuat peraturan perundang-undangan, tidak berarti negara tidak terikat olehnya. Cara kedua, "imposes restrictions on the law itself, erecting limitations on the law making power of the government." 20 Konsekuensi yang timbul adalah:

certain prohibited actions cannot be legally allowed, even by a legitimate lawmaking authority. Legal restrictions of this sort rank above (control over) ordinary lawmaking. The most familiar versions of this are: 1) constitutionally imposed limits, 2) transnational or international legal limits, 3) human rights limits, and 4) religious or natural law limits. In different ways and senses, these types of law are superior to and impose restraints upon routine law making. ${ }^{21}$

Berdasarkan asas the Rule of Law maka dalam melakukan kriminalisasi kewenangan pembentuk undangundang tidak bebas (tidak tanpa batas). Hal itu karena kriminalisasi merupakan bagian dari kekuasaan legislasi di mana kekuasaan legislasi sendiri secara umum sudah menjadi objek pembatasan oleh asas the Rule of Law yang berimplikasi bahwa pembentuk undang- undang tidak boleh membentuk undangundang sesuai kehendaknya sendiri.

Isu yang saat ini problematik dalam hubungan antara negara dan warga negara adalah aktivitas pengaturan oleh negara yang dilakukan secara berlebihan (over). Semakin banyak peraturan perundang-undangan tidak menjadikan situasinya lebih baik, terlebih kemudian peraturan perundang-undangan tersebut hanya berlaku di atas kertas. Oleh karena itu, sebagai kaidah, Tamanaha mengatakan: "To be consistent with the rule of law, the law need not cover everything, but what the law does cover should be largely adhered to by the citizenry." 22 Dikaitkan dengan potensi intervensionis negara melalui pengaturan maka yang harus menjadi perhatian serius adalah hakikat sesungguhnya dari pengaturan tersebut supaya tidak terjadi situasi penyalahgunaan kekuasaan atau tindakan sewenang-wenang dalam pembentukan peraturan perundangundangan (termasuk kriminalisasi).

Hal ini sekaligus mengamini argumen Tamanaha di atas: tidak perlu segala hal diatur atau hanya hal-hal yang benar-benar perlu saja yang membutuhkan pengaturan. Jika pengaturan dilakukan maka pengaturan tersebut harus konsisten dengan the Rule of Law (dalam arti luas), yaitu harus secara efektif membatasi kekuasaan intervensionis negara, memberikan

Nina Persak, Op.Cit. 1.

Brian Z. Tamanaha, Op.Cit. 4.

Ibid. 4-5.

Ibid. 5. 
kejelasan mengenai perikelakuan para subjek hukum dan kejelasan mengenai sanksi atas pelanggaran yang terjadi guna mencegah supaya warga negara tidak menjadi korban kesewenangwenangan penguasa.

Kesimpulan dari pembahasan di atas adalah, dalam konteks asas the Rule of Law, pembatasan dalam pembentukan undang-undang secara umum sangat perlu untuk dibatasi. Aktivitas pengaturan oleh negara (pembentuk undang-undang) memiliki pengaruh sangat besar terhadap kebebasan individu. Implikasi pengurangan terhadap kebebasan individu inilah, dari perspektif asas the Rule of Law, yang menjadikan perlunya aktivitas pengaturan oleh negara (pembentuk undang-undang) untuk selalu ditanggapi serius supaya tidak berlaku menjadi kebebasan pembentuk undang-undang, tetapi harus berada di bawah kontrol hukum, dalam hal ini asas the Rule of Law itu sendiri.

\section{Kriminalisasi yang Legitimate versus Kriminalisasi yang Tidak Legitimate}

Dewasa ini, banyaknya aktivitas pengaturan oleh negara (pembentuk undang-undang) terutama yang dilengkapi dengan ancaman sanksi pidana, mulai menjadi concern tidak hanya oleh yuris konstitusional, tetapi juga yuris pidana itu sendiri. Pembentukan undang-undang yang disertai dengan ancaman sanksi pidana (kriminalisasi) dipandang menjadi salah satu ancaman paling serius terhadap individu, terlebih ketika keputusan mengkriminalkan suatu tindakan melalui undang-undang tersebut dilakukan secara serampangan.

Sejalan dengan pembahasan sebelumnya, berdasarkan the Rule of Law maka dalam melakukan kriminalisasi kewenangan pembentuk undang-undang (legislator) tidak bebas (tidak tanpa batas). Oleh karena itu pembatasan terhadap kewenangan legislator untuk melakukan kriminalisasi perlu dianalisis secara khusus terutama untuk menjawab permasalahan cakupan kriminalisasi yang diperbolehkan (legitimate) dan yang tidak diperbolehkan (tidak legitimate). Dengan pengertian lain, analisis yang dilakukan akan difokuskan pada kriteria kriminalisasi yang diperbolehkan atau kriminalisasi yang legitimate. Fenomena kriminalisasi yang melampaui batasan tersebut secara teoretis (menurut Teori Hukum Pidana) disebut dengan istilah overcriminalization.

Konsep overcriminalization memiliki pengertian: "the abuse of the supreme force of a criminal justice system-the implementation of crimes or imposition of sentences without justification." 23 Pengertian ini masih kabur. Oleh karena itu Erik Luna mengemukakan definisi yang lebih operasional dengan kriteria: "(1) untenable offenses; (2) superfluous statutes; (3) doctrines that overextend culpability; (4) crimes without jurisdictional authority; (5) grossly disproportionate

$22 \quad$ Ibid. 7.

23 Erik Luna, ‘The Overcriminalization Phenomenon' (2005) 54 American University Law Review 703, 715 . 
punishments; and (6) excessive or pretextual enforcement of petty violations." ${ }^{24}$

Berdasarkan asas the Rule of Law yang esensinya mengandung makna pembatasan terhadap kekuasaan pemerintah di semua bidang tindakan, maka overcriminalization tidak diperbolehkan. Undang-undang pidana yang terkatagori overcriminalization melanggar atau bertentangan dengan asas the Rule of Law. Hal itu adalah isu yang problematik dalam hubungan antara negara dan warga negara saat ini adalah aktivitas pengaturan oleh negara yang dilakukan secara berlebihan (over).

Andrew Ashworth yang bertolak dari pemikiran Sanford $H$. Kadish mengemukakan argumen sedikit berbeda dengan pendapat sebelumnya dalam memandang fenomena kriminalisasi dan overcriminalization. Ashworth berpendapat bahwa kriminalisasi dan hukum pidana bukan satu-satunya instrumen dalam rangka mengatur perilaku subjek hukum. Tesis Ashworth tentang overcriminalization adalah terlampauinya fungsi yang legitimate dari hukum pidana karena pembentuk undang-undang (legislator) mengabaikan perbedaan antara criminal law dan regulatory laws. Menurut Ashworth:

There is a sense that the criminal law is not simply one of a range of techniques available to the legislature for regulating the conduct and activities of subjects. A wide range of regulatory regimes now offer themselves, from licensing to franchising, from financial regulation to environmental standards and so forth. Most modern democracies include a number of statutory regulatory bodies, charged with the task of regulating particular activities. The civil law also regulates conduct in many ways, although it typically leaves it to the aggrieved party to initiate enforcement measures. ${ }^{25}$

Pendapat Ashworth menarik karena mengaitkan kriminalisasi (dan hukum pidana) dengan keberadaan bidangbidang hukum lain yang pada hakikatnya memiliki sifat atau karakter yang sama yaitu untuk mengatur perilaku subjek hukum. Dikaitkan dengan keberlakuan bidang-bidang hukum lainnya sebagai instrumen bagi negara dalam melakukan pengaturan maka pendapat Ashworth ini dapat bermakna bahwa kriminalisasi suatu tindakan adalah ultimum remedium (upaya terakhir). Jika sebaliknya, maka kriminalisasi tersebut patut diberikan penilaian sebagai upaya overcriminalization, yaitu kriminalisasi yang tidak legitimate.

Sarjana lain yang secara spesifik dan komprehensif menggunakan konsep overcriminalization sebagai bentuk tanggapan terhadap kriminalisasi yang tidak legitimate adalah Douglas Husak. Bahkan jika ditelusuri lebih jauh, argumen Baker adalah bertolak dari argumen Husak. Konsep overcriminalization ini digunakan Husak untuk menggambarkan kondisi terlalu banyaknya ancaman pidana yang dibuat oleh negara terhadap warganya (the

$24 \quad$ Ibid. 716.

25 Andrew Ashworth, 'Conceptions of Overcriminalization' (2008) 5 Ohio State Criminal Law Journal $407,408$. 
massive increase in State punishment atau too much punishment). ${ }^{26}$ Dalam mendiskusikan tentang overcriminalization, target Husak adalah menghasilkan teori kriminalisasi, yaitu "a normative framework to distinguish those criminal laws that are justified from those that are not." 27 Pendapat Husak pada hakikatnya merupakan tanggapan atas fenomena yang ditemukan dan dihadapi oleh negaranya, yaitu Amerika Serikat, yang menurutnya: "We overpunish and overcriminalize." 28

Sudut pandang dari teori Husak adalah kriminalisasi dan hukum pidana merupakan ultimum remedium. Karena itu ada batas-batas bagi dapat tidaknya suatu tindakan dikriminalisasi, sehingga pada akhirnya apakah tindakan itu memang dapat atau layak menjadi objek dari hukum pidana ataukah tidak. Husak mengemukakan ada dua batasan utama dalam kriminalisasi, yaitu: "internal constraints on criminalization" (batas-batas kriminalisasi dari dalam hukum pidana sendiri) dan "external constraints on criminalization" (batasbatas kriminalisasi dari luar hukum pidana).

Pandangan mutakhir terkait dengan isu legitimasi kriminalisasi yang dilakukan pembentuk undang-undang adalah digunakannya pendekatan HAM dalam menilai secara ex ante maupun ex post terhadap kriminalisasi. Baker mengkritik kriminalisasi yang dilakukan pembentuk undang-undang dengan mengklaim adanya the right not to be unfairly criminalized. Dengan mengajukan tesis hak tersebut tidak berarti bahwa Baker menolak suatu tindakan dikriminalisasi sama sekali, tetapi yang ditolak adalah unprincipled criminalization atau unfair criminalization. Dalam membangun argumennya Baker bertolak dari hubungan antara Hukum Tata Negara dengan Hukum Pidana. Hukum Tata Negara, dengan muatan hak-hak konstitusional di dalamnya, bersifat membatasi tindakan kriminalisasi oleh pembentuk undang-undang yang menghasilkan hukum pidana material. Baker menyatakan tesis yang dipertahankannya dalam mengkritisi kriminalisasi oleh pembentuk undangundang sebagai berikut: "the moral criteria for constraining unjust criminalization can and have been incorporated into constitutional human rights and thus provide us with a legal right not to be unfairly criminalized. The aim of the book is to set out the constitutional limits of the substantive criminal law." ${ }^{29}$

Perhatian utama Baker adalah "ensuring that people are only criminalized when they deserve it." 30 Pemikiran yang mendasarinya: "Criminalization has harmful 2008) 3.

27 Ibid.

28 Ibid. 4.

29 Dennis J. Baker, Op.Cit. 1. 
consequences for those who are labeled as criminals and therefore people have a right not to be criminalized unless it is fair to override their right." ${ }^{11}$ Yang dimaksud dengan harmful consequences adalah dikenakannya sanksi pidana yang bersifat memberi nestapa kepada diri terpidana. Sehingga, menentukan suatu tindakan sebagai tindak pidana harus didasari justifikasi yang mampu mengesampingkan hak untuk tidak dikriminalisasi tersebut. Pemikiran ini di-back up argumen: "The right to not to be criminalized is a basic human right that aims to protect individuals from unwarranted state interference of a penal nature." ${ }^{32}$ Pada poin ini pendapat Baker konsisten atau memiliki titik temu dengan pendapat para sarjana lainnya dalam menentukan kriteria kriminalisasi yang legitimate. Lebih lanjut Baker mencontohkan bentuk-bentuk praktik unjust and unfair criminalization:

the mislabeling of innocuous conduct as criminal; eliminating the ex post culpability requirement without moral justification (strict and vicarious liability for crimes that result in a conviction and/ or imprisonment); eliminating the ex ante 'imputability of blame for remote harm' requirement without justification (i.e., criminalizing people for being a mere 'but for' cause of harm caused by the intervening choices of others: remote harms); imposing disproportional punishments; and through the circumvention of human rights and due process protections by, for example, blurring the civil and criminal law. ${ }^{33}$

Ibid. 2.

Ibid.

Ibid. 9.

Ibid.

Ibid. 1.
Secara teoretis hak untuk tidak dikriminalisasi secara unfair dan unjust mengandung konteks pembatasan terhadap kekuasaan negara untuk melakukan kriminalisasi dengan pengertian: supaya kriminalisasinya legitimate maka kriminalisasi tersebut harus just and fair. Baker menyatakan misi dari studinya:

There is a vast array of literature on the moral limits of the criminal law. In this book my goal is not merely to discuss the moral limits of the criminal law. Instead, the focus is on the legal limits of the criminal law. This book takes a different approach by trying to show how the moral criteria for constraining unjust criminalization can and have been incorporated into constitutional human rights and thus provide us with a legal right not to be unfairly criminalized. The aim of the book is to set out the constitutional limits of the substantive criminal law. ${ }^{34}$

Pernyataan di atas sangat menarik dan provokatif untuk menunjukkan satu aspek sangat substansial bahwa setiap orang memiliki hak untuk tidak dikriminalisasi pada satu sisi; sementara di sisi lain respons terhadap kriminalisasi yang dilakukan oleh negara cenderung permisif, sehingga timbul fenomena overcriminalization. Pada poin ini menurut hemat penulis ada satu hal penting yang perlu digaris bawahi yaitu: Apakah hak untuk tidak dikriminalisasi secara unjust dan unfair tersebut valid dan otoritatif untuk membatasi kekuasaan melakukan kriminalisasi yang dimiliki oleh negara 
(dijalankan oleh pembentuk undangundang atau legislator)?

Baker sama sekali tidak mengabsolutkan hak untuk tidak dikriminalisasi. Proporsionalitas dari kriminalisasi tersebut yang menjadi perhatian utama Baker:

In this book I have examined the legal limits of the substantive criminal law. In doing so, I have formulated a constitutional right not to be criminalized. I have argued that right can only be overridden when the State can produce a compelling justification for overriding it. If the criminalization involves jail time, the compelling justification for overriding the right would have to be that the offender's conduct results in harms for others. ${ }^{35}$

Hal itu nampak dari batasan dari Baker terhadap kemungkinan negara dapat melakukan pengesampingan terhadap hak tersebut dengan syarat "... State can produce a compelling justification for overriding it." Produce a compelling justification untuk kriminalisasi adalah isu utama yang dihadapi oleh negara dalam menjalankan kekuasaan melakukan kriminalisasi. Permasalahan utama tersebut adalah membangun suatu konsensus mengenai compelling justification. Warga negara sebagai adresat dari ketentuan hukum pidana materiil produk dari pelaksanaan kekuasaan melakukan kriminalisasi harus mampu diyakinkan oleh negara bahwa produk kriminalisasinya rasional, adil dan memang diperlukan. Hal ini harus melampaui batasan bahwa kriminalisasi dilakukan karena negara semata-mata menghendakinya.
Diskusi tentang kriminalisasi yang adil supaya legitimate sangat penting karena kesadaran tentang kemungkinan negara menyalahgunakan kekuasaan dalam membentuk undang-undang ketika melakukan kriminalisasi:

We implicitly agree to have law in order to maintain society for the good of humanity, but we also realize that the State might misuse the law or simply get it wrong. Thus, the law itself has to be subject to a number of fairness constraints. The state is merely members of society acting as a collective and we need to know why the commands of the majority as expressed in laws have authority over us as individuals. ${ }^{36}$

Dalam kaitan dengan permasalahan kriminalisasi yang adil maka pertanyaan utamanya adalah kriteria atau parameter untuk menentukan suatu perbuatan sebagai perbuatan jahat sehingga layak dikriminalisasi dan sekaligus dikenakan ancaman sanksi pidana. Baker menjelaskan bahwa untuk memperoleh kriteria objektif dan dapat digeneralisasi tidaklah mudah, khususnya dikaitkan dengan tujuan yang hendak dicapai dalam rangka melakukan kriminalisasi:

constraints such as the harm and culpability constraints are only objective to the extent that there is deep conventional agreement about what constitutes a punishable harm, but once we get into territory where there is disagreement about what ends are intersubjectively sharable by all agents communally situated, a principled case for criminalization is difficult to identify. ${ }^{37}$

Isu utama terkait dengan legitimasi kriminalisasi adalah menjamin 
objektivitas dalam melakukan kriminalisasi yang tujuannya untuk membatasi kriminalisasi oleh negara. Dalam hal ini Baker menyatakan pendapatnya:

The issue of objectivity even in the limited conventional sense is fundamental, as it can explain the wrongness of actions such as genocide, murder, rape and so forth. Reason allows inter-subjective thinkers to see that the gross physical harm-doing involved in culpable genocide is objectively bad and wrong regardless of the context or circumstances. Conventionally it is understood as a gross and wanton use of human life. ${ }^{38}$

Dalam pendapat tersebut Baker menekankan perlunya akal budi untuk menghasilkan pemahaman intersubjektif guna menjelaskan sifat tercela atau jahatnya perbuatan (the wrongness of action) sebagai justifikasi bagi kriminalisasi yang dilakukan. Dengan contoh kejahatan-kejahatan tradisional seperti genosida, pembunuhan dan perkosaan maka sifat tercela atau jahatnya perbuatan tersebut jelas dengan sendirinya karena perbuatan jahat tersebut ditujukan kepada kehidupan manusia sehingga kriminalisasi terhadap perbuatan tersebut adalah suatu kebutuhan yang objektif.

Pada analisis akhir Baker mengusulkan supaya pembentuk undang-undang melakukan analisis evaluatif ex post terhadap produk kriminalisasinya berdasarkan pertimbangan keadilan dan proporsionalitas untuk tetap memberikan jaminan terhadap hak untuk tidak dikriminalisasi secara unjust dan unfair: "Proportionality and justice require the lawmaker to consider the harmfulness or badness of the potential consequences that are being criminalized along with the potential degrees of culpability that may be involved." ${ }^{39} \mathrm{Hal}$ ini untuk memungkinkan dilakukannya dekriminalisasi terhadap produk kriminalisasi pembentuk undangundang yang sudah tidak sesuai dengan perkembangan kemasyarakatan.

\section{PENUTUP}

Berdasarkan pembahasan di atas yang menganalisis isu kriminalisasi dari perspektif Teori Hukum Pidana maka nampak beberapa pengertian yang sifatnya sangat prinsip sebagai berikut. Pertama, kriminalisasi harus diletakkan dalam kekuasaan legislasi pada pembentuk undang-undang. Dalam pengertian demikian maka asas yang sangat fundamental adalah pembatasan terhadap kekuasaan pembentuk undang-undang dalam membentuk undang-undang atau legislasi yang substansi atau materi muatannya adalah menetapkan suatu tindakan sebagai tindak pidana dan ancaman sanksi pidananya (kriminalisasi). Pembatasan tersebut didikte oleh asas konstitusional yaitu the Rule of Law.

Kedua, pembatasan oleh asas the Rule of Law ini tertuju pada dua hal. Pertama, kekuasaan membentuk undang-undangnya secara umum. 
Kedua, keputusan pembentuk undangundang dalam melakukan kriminalisasi secara khusus. Tentang yang terakhir ini hasil pembahasan di atas telah menjelaskan secara gamblang perbedaan antara kriminalisasi yang legitimate dan kriminalisasi yang tidak legitimate.

Ditinjau dari bidang kajian Hukum Pidana maka isu pengujian legitimasi kriminalisasi yang dilakukan oleh pembentuk undang-undang dewasa ini mulai disadari sebagai isu sangat serius untuk menjadi objek kajian Teori Hukum Pidana. Hasil dari kajian tersebut diharapkan dapat menjadi pedoman yang sangat mantap bagi pembentuk undang-undang dalam merancang kebijakan kriminalisasi untuk menghasilkan undang-undang pidana (hukum pidana material) yang benar.

\section{DAFTAR BACAAN}

\section{Buku}

Baker, Dennis J., The Right Not To Be Criminalized: Demarcating Criminal Law's Authority (Ashgate Publishing Company 2011).

Gallant, Kenneth S., The Principle of Legality in International and Comparative Criminal Law (Cambridge University Press 2009).

Husak, Douglas, Overcriminalization: The Limits of the Criminal Law (Oxford University Press 2008).
Marzuki, Peter Mahmud, An Introduction to Indonesian Law (Setara Press 2011).

Moeljatno, Asas-asas Hukum Pidana (Penerbit Rineka Cipta 1993).

Persak, Nina, Criminalising Harmful Conduct: The Harm Principle, Its Limits and Continental Counterparts (Springer 2007).

Raz, Joseph, The Authority of Law (Clarendon Press 1983).

Wilson, William, Central Issues in Criminal Theory (Hart Publishing 2002).

\section{Bab dalam Buku}

Husak, Douglas, 'Overcriminalization' dalam Dennis Patterson, ed., A Companion to Philosophy of Law and Legal Theory (Blackwell Publishing Co., 2010).

Inoue, Tatsuo, 'The Rule of Law as the Law of Legislation' dalam Luc J. Wintgens, ed., Legislation in Context: Essays in Legisprudence (Ashgate Publishing Company 2007).

Peerenboom, Randall, 'Varieties of Rule of Law' dalam Randall Peerenboom, ed., Asian Discourses of Rule of Law (Routledge 2004).

Tamanaha, Brian Z., 'A Concise Guide of the Rule of Law' dalam Gianluigi Palombella dan Neil Walker, eds., Relocating the Rule of Law (Hart Publishing 2009). 


\section{Jurnal}

Cass R. Sunstein, 'Problems with Rules' (1995) 83 California Law Review 953.

Erik Luna, 'The Overcriminalization Phenomenon' (2005) 54 American University Law Review 703.

Andrew Ashworth, 'Conceptions of Overcriminalization' (2008) 5 Ohio State Criminal Law Journal 407. 
